Nat. Hazards Earth Syst. Sci. Discuss., https://doi.org/10.5194/nhess-2017-365

Manuscript under review for journal Nat. Hazards Earth Syst. Sci.

Discussion started: 27 October 2017

(c) Author(s) 2017. CC BY 4.0 License.

\title{
1997 Typhoon Linda Storm Surge and People's Awareness 20 Years Later: Uninvestigated Worst Storm Event in the Mekong Delta
}

Hiroshi Takagi ${ }^{1}$, Le Tuan Anh ${ }^{1}$, Nguyen Danh Thao ${ }^{2}$

${ }^{1}$ Tokyo Institute of Technology, School of Environment and Society, Tokyo, Japan

$5 \quad{ }^{2}$ Ho Chi Minh City University of Technology, Faculty of Civil Engineering, Ho Chi Minh, Vietnam

Correspondence to: H. Takagi (takagi@ide.titech.ac.jp)

\section{Abstract.}

Typhoon Linda (1997) was the worst storm in the Mekong Delta. However, very little scientific information is available. Of the last 228 storms to make landfall in Vietnam, this tropical cyclone took the southernmost course,

10 and the estimated reoccurrence period is once in 150 years or longer. Our analysis reveals that the storm surge reached $1.5-\mathrm{m}$ high along the eastern coast of the low-lying delta, and it even propagated until the regional capital of Can Tho, which is located 80-km inland from the river mouth. Despite the fact that local people in Can Tho still clearly remember Linda after almost 20 years, curiously all of the interviewees replied, 'I am not afraid of a typhoon'. On the other hand, the islanders of Con Dao, which was directly impacted by Linda, acknowledged a high degree of awareness of typhoon disasters. This study demonstrates that only a memory of the past significant event does not necessarily improve people's awareness. Because the delta was a nearly uninhabited mangrove jungle before the 20th century, this particular typhoon event needs to be better studied to envisage a future catastrophic 'gray swan' event. 
Nat. Hazards Earth Syst. Sci. Discuss., https://doi.org/10.5194/nhess-2017-365

Manuscript under review for journal Nat. Hazards Earth Syst. Sci.

Discussion started: 27 October 2017

(c) Author(s) 2017. CC BY 4.0 License.

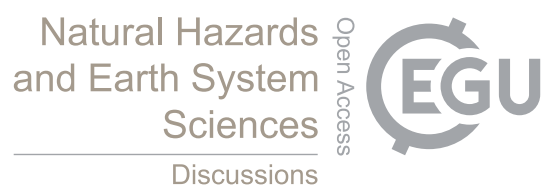

\section{INTRODUCTION}

Although Vietnam is a typhoon-prone country, relatively little research has been conducted on typhoons and storm surges along its coast. Cyclones rarely form in a low-latitude oceanic basin due to smaller influence of the Earth's rotation. Consequently, the risk of a typhoon disaster in Southern Vietnam, which includes the Mekong

5 Delta (hereinafter MD), tends to be overlooked due to the low frequency compared to Northern and Central Vietnam. However, typhoons sometimes venture into the southern part of Vietnam (Takagi et al., 2015; Anh et al., 2017).

Typhoon Linda (meteorologically categorized as a severe tropical storm) in 1997 is considered to be the worst tropical cyclone ever to make landfall in southern Vietnam. Linda hit MD, killing over 3,000 people and causing US\$385 million of damage. Heavy rainfall induced flooding, which damaged or destroyed about 200,000 houses and left about 383,000 people homeless. The fatalities were mostly fishermen and sailors, who were caught at sea in its path and unable to escape (Nation, Nov 6 1997; UNDP, 2003). Linda also affected Cambodia where at least 23 people died and over 200 people are missing (Hong Kong Observatory, 1998) and Thailand where 12 died and an unknown number of fishermen are still missing (The Nation, Nov 15, 1997a). Winds from Linda fanned flames from Indonesian peat fires and swept smog into neighboring Southeast Asian countries, causing serious air pollution (The Nation, Nov 6, 1997b). Some previous studies revealed that Linda generated a strong northeasterly wind. Consequently, the storm surge was up to $70 \mathrm{~cm}$ in the northwestern part of the Gulf of Thailand (Aschariyaphotha et al., 2011) and the wind waves were nearly $3 \mathrm{~m}$ (Wannawong et al., 2010).

Few studies have examined the damage Linda caused in Vietnam, despite extensive devastation. Particularly, the physical impact due to storm surge has yet to be investigated. There may be some literature documented by governmental institutes or local authorities, but it is hard for ordinary researchers to access. This limited information about Linda differs from other recent major coastal disasters occurring in neighboring countries (e.g., 2004 Indian Ocean Tsunami, 2011 Tohoku Tsunami, and 2013 Typhoon Haiyan). These recent disasters have been extensively investigated by local and international researchers (Esteban et al., 2015a).

The most severely affected provinces such as $\mathrm{Ca}$ Mau and Bac Lieu were remote areas that remained inaccessible by roads for many weeks after the disaster (The Nation, Nov 15, 1997a). Additionally, Vietnam's bureaucracy at that time might have made it difficult for non-governmental organizations or researchers to investigate in the Mekong region. Nevertheless, it is worth noting that the deadliest 2008 Cyclone Nargis in Myanmar has been substantially investigated by at least several international research groups even under a military regime with a strong closed-door policy, and has contributed to the general understanding of damage due to strong winds and storm surges (Shibayama et al., 2008; Fritz et al., 2009; Tasnim et al., 2015). To a lesser degree, the non- 
Nat. Hazards Earth Syst. Sci. Discuss., https://doi.org/10.5194/nhess-2017-365

Manuscript under review for journal Nat. Hazards Earth Syst. Sci.

Discussion started: 27 October 2017

(c) Author(s) 2017. CC BY 4.0 License.

availability of information in the case of Linda may be due to the limited mobility of international researchers because the internet environment in those days was insufficient to promptly conduct post-disaster surveys abroad. In this study, we revisit Typhoon Linda to understand the characteristics of its track and the extent of the storm surge caused by strong winds. A major disaster tends to rapidly raise awareness, but the awareness gradually

5 decays (Esteban et al., 2015b). To gage the state of people's awareness 20 years after Linda, we also conducted a series of field surveys to examine whether such a catastrophic event has changed people's mindset about typhoon disasters.

\section{METHODOLOGY}

10 This section first describes the statistical analysis of landfall of tropical cyclones on Vietnam. The numerical model that simulates typhoon and storm surge is then briefly explained. Finally, field surveys conducted in the Mekong Delta and a remote island are described.

\subsection{TC Landfall Analysis}

15 The original data for the TC track analysis were retrieved from the database of the Joint Typhoon Warning Centre (JTWC) (http://www.usno.navy.mil/NOOC/nmfc-ph/RSS/jtwc/best tracks/wpindex.php). We developed a program code to detect the landfall location at which a typhoon track intersects the coastline retrieved from Google Earth. Wind speeds at the time of landfall were also estimated by interpolating the best track data at two points before and after the landfall. In the extreme value analysis, many theoretical distribution functions were employed to fit the samples. The Generalized Extreme Value (GEV) distribution, which combines the Gumbel, Fréchet, and Weibull families, is often used in the statistics of extreme events such as extreme rainfalls (Koutsoyiannis, 2004) and extreme wind speeds (Palutikof et al., 1999). Typhoon Linda made landfall on the southernmost coast of Vietnam over two decades ago. Here we employed GEV to estimate the return period of Linda in terms of landfall latitude. Among the many plotting rules proposed for the extreme value analysis (Goda, 2000), the Cunnane formula was applied as the plotting position in this study.

\subsection{Typhoon and Storm Surge Simulation}

We used the fluid dynamics model Delft3D-FLOW coupled with our parametric typhoon model developed to simulate the storm surge during the passage of Linda. The reliability of our model was verified for some strong typhoons, such as 2013 Typhoon Haiyan (Takagi et al., 2017) and 2015 Typhoon Goni (Takagi and Wu, 2016). The typhoon model calculated both the pressure and wind fields using parameters obtained from the JMA TC 
Nat. Hazards Earth Syst. Sci. Discuss., https://doi.org/10.5194/nhess-2017-365

Manuscript under review for journal Nat. Hazards Earth Syst. Sci.

Discussion started: 27 October 2017

(c) Author(s) 2017. CC BY 4.0 License.

Best Track Data set (http://www.jma.go.jp/jma/jma-eng/jma-center/rsmc-hp-pub-eg/trackarchives.html). That is, the central positions and pressures at every recording period were used as parameters. The maximum wind radius, which was not contained in the best track data, was estimated from the central pressure (Takagi and Wu, 2016). Figure 1 shows the time series of the sea surface pressure and wind speed at Con Dao close to the storm track, as 5 derived from the typhoon model.

Although the Delft3D model can be applied to three-dimensional phenomena, the present study used a twodimensional horizontal grid. Thus, the code becomes a shallow-water wave model, which is commonly used to simulate a long wave such as storm surges, tsunamis, and tidal propagation. Oceanic bathymetry within the computational domain was obtained from the General Bathymetric Chart of the Oceans (GEBCO). The computational domain encompassed a wide area that included MD between $5.44^{\circ} \mathrm{N}-105.97^{\circ} \mathrm{E}$ and $12.86^{\circ} \mathrm{S}-$ $108.13^{\circ} \mathrm{E}$ (Fig. 1).

\subsection{Tidal Analysis}

We gathered water level data, encompassing the period of Linda, measured at three observatories (Can Tho, My Thanh, and Ganh Hao). Ordinary tidal prediction techniques were applied to detect anomalies in the water levels induced by the typhoon storm surge of Linda. The main tidal constituents for two coastal stations (My Thanh and Ganh Hao) were derived from the TPXO 7.1 Global Inverse Tide Model (Egbert and Erofeeva, 2002), whereas those in Can Tho, which also contains fluvial influences, were assumed by the reference (Takagi et al., 2016a) (Table. 1).

\subsection{Field Survey}

Con Dao Island is located off the southeastern tip of Vietnam about $230 \mathrm{~km}$ south of Ho Chi Minh City (HCM), while Can Tho City is situated $150 \mathrm{~km}$ southwest of HCM. We conducted a structured questionnaire survey among the local inhabitants of Can Tho and Con Dao in December 2015 and March 2017, respectively. Our primary intent was to investigate the residents' memory of Typhoon Linda (1997) as well as to assess general awareness of typhoon disasters. We asked whether they remembered Linda. Specifically, we asked if they could recall the degree of wind intensity, inundation, and whether they evacuated during Linda. A total of 205 valid responses were collected in the two locations (Table 2).

Although we initial thought about visiting the coastal area directly hit by Linda, the location is very remote (Fig. 2). The lack of populated villages would prevent identifying a sufficient number of interviewees. Alternatively, we conducted interviews in Con Dao Island with the expectation that we could gather responses from people 
Nat. Hazards Earth Syst. Sci. Discuss., https://doi.org/10.5194/nhess-2017-365

Manuscript under review for journal Nat. Hazards Earth Syst. Sci.

Discussion started: 27 October 2017

(c) Author(s) 2017. CC BY 4.0 License.

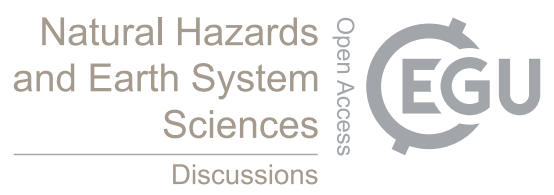

(c) (i)

directly impacted by Linda. Meanwhile, Can Tho was more than $100 \mathrm{~km}$ away from the track of Linda (Fig. 2). It was speculated that Can Thao sustained less damage, but there was not a published report describing the situation in Can Tho during Linda. For this reason and given the importance of this city as the regional capital, we also visited Can Tho. We administered the structured questionnaire based on the initial version drafted in English,

5 which was translated into Vietnamese. The questionnaire was distributed to individuals encountered on an opportunistic basis (Fig. 2).

\section{RESULTS}

$10 \quad 3.1$ Statistics of tropical cyclones in Vietnam and uniqueness of Typhoon Linda

The best-track data of the Joint Typhoon Warning Centre (JTWC) was used to analyze the frequency and spatial distribution of tropical cyclone (TC) landfalls between 1945 and 2014 in Vietnam (Fig. 3). In the past seven decades, 228 TCs have crossed the coastline, resulting in an average of 3.26 TCs per year. This frequency is smaller than that of the Philippines (5.9 times per year between 1945 and 2013, Takagi and Esteban, 2016) but is similar with that in Japan (2.9 times per year between 1951-2016, JMA, http://www.data.jma.go.jp/fcd/yoho/typhoon/statistics/landing/landing.html). The annual landfall frequency of TCs appears to increase with latitude, which can be adequately modeled with $F=0.058$ Latitude $-0.36\left(R^{2}=\right.$ 0.877).

Linda formed as a tropical depression about $340 \mathrm{~km}$ south of the Spratly Islands on November $1^{\text {st }}$. It tracked westwards and intensified into a severe tropical storm. The storm made landfall in MD on November $2^{\text {nd }}$ (Hong Kong Observatory, 1998) $)^{5}$. The present study based on the best-track data indicates that Linda landed on the coast at $105.44^{\circ} \mathrm{E}-9.007^{\circ} \mathrm{N}$ with a forward speed of $25.6 \mathrm{~km} \mathrm{hr}^{-1}$. The maximum wind speed of 55 knots was not extremely strong, but still ranks in the 70th percentile of all TCs.

The southernmost latitude zone $\left(9.0^{\circ} \mathrm{N}-11.0^{\circ} \mathrm{N}\right)$ included in Figure 3 has only encountered 11 TCs over the last seven decades, which is a remarkably low frequency compared to the rest of Vietnam's coast. It should be noted that Linda took the lowest course, crossing almost the southern end of the delta. The extreme value statistics using the generalized extreme value (GEV) suggests that the return period of a typhoon with a similar course is once every 150 years or longer (Fig. 4). 
Nat. Hazards Earth Syst. Sci. Discuss., https://doi.org/10.5194/nhess-2017-365

Manuscript under review for journal Nat. Hazards Earth Syst. Sci.

Discussion started: 27 October 2017

(c) Author(s) 2017. CC BY 4.0 License.

We visited Ca Mau Cape in March 2014, which is on the south tip of Vietnam, to search for records of the storm surge during Linda. Although tidal records were not found, the estimated range of surge height in this area was 0.9-1.0 $\mathrm{m}$ through interviews with two local residents (Fig. 1). On the other hand, the time series of water levels around the passage of Linda was obtained from three observatories (Can Tho, My Thanh, and Ganh Hao). The

5 storm surge components were detected by subtracting the astronomical tidal levels from the observed water levels. The background map in Fig. 1 shows the distribution of the maximum surge heights generated by the typhoon hydrodynamic coupling model. The analysis suggests that the abnormal water level reached $1.5 \mathrm{~m}$ at the Ganh Hao station, which is situated adjacent to the landfall point. The numerical simulation also shows that the seawater concentrated on the concave coast, resulting in an anomaly up to $1.8 \mathrm{~m}$.

Regarding Can Tho City, the tidal analysis and numerical simulation both show that a substantial storm surge with the height of about $0.5 \mathrm{~m}$ occurred. Many local residents, who lived by the river, recalled that their houses were inundated with about $0.2-0.5 \mathrm{~m}$ (Table 2). On the other hand, the storm surge at My Thanh, which is located at the river mouth, was about $0.8 \mathrm{~m}$. This was slightly higher than that at Can Tho. The reduction in amplitude between two locations implies that storm surge was attenuated during the course of propagation due to bottom friction and counter river discharge.

These observations demonstrate that storm surge propagated in the main river over a long distance (about $80 \mathrm{~km}$ ) and reached the largest city in MD. To the authors' best knowledge, the inundation caused by Linda has yet to be studied despite the fact that the storm surge led to the historical highest water level in Can Tho. In fact, a water level up to $1.84 \mathrm{~m}$ observed in 1997 was used as a design water level of the Can Tho Bridge (one of the longest bridges in Southeast Asia), which is equivalent to a once-in-a-century flood event (JICA, 2000). However, it seems that this maximum water level was not properly analyzed as the storm surge height during the design procedure of the bridge due to the lack of scientific information on Typhoon Linda.

\subsection{Memory of Linda and Awareness of Typhoon Disasters}

25 We conducted questionnaire surveys in Con Dao Island and Can Tho. In all, we interviewed a total of 205 local people (Table 2). Although the interviewees were encountered on an opportunistic basis, the gender, age, and occupations were widely distributed. It is remarkable that $83.5 \%$ and $100 \%$ of the respondents in Con Dao and Can Tho, respectively, remembered Typhoon Linda, demonstrating how a single event can be imprinted as an unforgettable memory among the local population. The reason why not all recalled Typhoon Linda (16.5\%) in Con Dao is attributed to the young respondents, who were born after the event. Additionally, some had recently migrated from the main land and did not live on the island during Linda. However, awareness of typhoons 
Nat. Hazards Earth Syst. Sci. Discuss., https://doi.org/10.5194/nhess-2017-365

Manuscript under review for journal Nat. Hazards Earth Syst. Sci.

Discussion started: 27 October 2017

(c) Author(s) 2017. CC BY 4.0 License.

(c) (i)

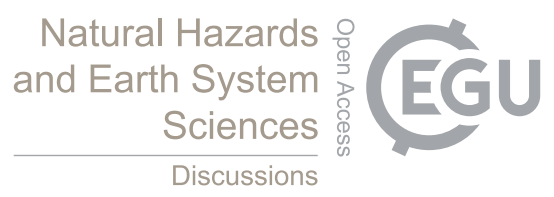

remarkably differed between the two regions. Interestingly, none of respondents in Can Tho were afraid of typhoon despite the fact that they all remembered Linda. Moreover, not all of them evacuated in the face of Linda. Many recalled flooded roads in Can Tho, and damaged houses due to strong winds or floods. Fortunately none of citizens in Can Tho died due to the direct impact of Linda. According to additional remarks from a couple of

5 respondents in Con Dao, none of the local people died on the island. However, many fishing boats, which departed from Con Dao and other parts of MD, including Can Tho, were lost offshore because they were unable to return to port. Many fishermen perished due to Linda. The wind appeared to be much stronger in Con Dao than Can Tho because the former was much closer to the typhoon's eye (see Fig.2). These results clearly demonstrate that a long memory of a specific disaster does not correlate to an increase in disaster awareness.

10

\section{DISCUSSION}

\section{Low frequency but high impact typhoon hazards}

There are two disaster patterns that can result in catastrophic consequences. However, their impacts differ. The first case is a catastrophe due to an unprecedented level of storm hitting an area where the population has a higher awareness because disaster events frequently occur. One such case may be Typhoon Haiyan in 2013, which made landfall in Leyte Island, the Philippines, and caused a maximum inundation height of up to 6-7 m (Takagi et al., 2016b; Mikami et al., 2016). The Philippines definitely suffers from frequent TCs. The return period of landfall of a Haiyan-class TC is estimated to be 200 years (Takagi and Esteban, 2016). Even local people familiar with frequent typhoon disasters could have underestimated the intensity and subsequent storm surge during Haiyan as it resulted in over 6,000 deaths (Esteban et al., 2016).

The other scenario is the case where an area rarely suffers from TCs and consequently, the local population cannot perceive what would happen due to an unprecedented event. A typical case of this type of catastrophe is Cyclone Nargis in 2008, which was one of the worst storm surge disasters ever recorded. Cyclone Nargis claimed nearly 140,000 lives in the Ayeyawady Delta, Myanmar due to the 4-6 m storm surge (Shibayama et al., 2008; Tasnim et al., 2015). Only a few cyclones have hit the southern coast of Myanmar in the last several decades (Shibayama et al., 2008). This situation is arguably different than that in neighboring Bangladesh, which has had at least 20 severe cyclonic storms make landfall since 1970 (Paul, 2009). Due to an almost complete lack of awareness of storm surges, many local inhabitants did not evacuated to safer areas during the course of Nargis (Shibayama et al., 2008). 
Nat. Hazards Earth Syst. Sci. Discuss., https://doi.org/10.5194/nhess-2017-365

Manuscript under review for journal Nat. Hazards Earth Syst. Sci.

Discussion started: 27 October 2017

(c) Author(s) 2017. CC BY 4.0 License.

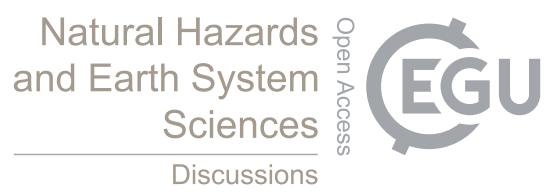

(c) (i)

A 'black swan' is a highly improbable event with three characteristics (Taleb, 2007): it is unpredictable; it carries a massive impact; and, after the fact, an explanation can be concocted that makes it appear less random, and more predictable, than it was. On the other hand, a "gray" swan is a near-black swan, but it is somewhat trackable scientifically. Gray swan events are rare but expected.

5 As mentioned earlier, the recurrence period of a Linda-like typhoon is estimated to be once every 150 years or longer, and it appears to be unusual. However, Linda should be categorized as a gray swan event. Thus, a future typhoon and storm surge in MD should be envisaged by examining only one past investigable typhoon, Linda.

\section{Seasonal flood vs. storm surge}

10 We demonstrated that Linda brought a substantial storm surge in Can Tho and caused a historical high water level about $80 \mathrm{~km}$ inland. Although it did not cause a devastating consequence, there are concerns that might decrease the abilities of local people to respond a future typhoon. Many citizens in Can Tho seem to adequately understand the general characteristics of disturbances triggered by typhoons such as strong winds, heavy precipitation, and flooding, based on their direct experience with Linda. However, they seem not to feel that a

15 similar event may have a life-threatening impact. People in MD have traditionally lived with floods. Thus, there is certain resilience among the residents in face of seasonal floods (Fig. 5). The seasonal inundation in Can Tho appears to be unavoidable. Flooding is estimated to occur 72 days per year (Takagi et al., 2016). It should be noted that such a tolerance to floods may adversely affect people's responses to real dangers. Although many respondents in Can Tho witnessed flooding around their houses, none of them evacuated during Linda (Table 2).

20 A gentle storm surge rising up to $50 \mathrm{~cm}$ might not have caused serious physical damage. However, they should have taken themselves to safer inland locations or higher buildings.

\section{Population increase in MD}

The current population of MD is 17 million, which is about $20 \%$ of the entire country (Central Population, 2010).

However, the delta was an undeveloped mangrove jungle prior to the 19th century, with a population density of only $10-20$ persons $/ \mathrm{km}^{2}$. From the 19 th to the early 20 th century, the population density reached 100 persons/ $\mathrm{km}^{2}$ (Danh et al., 2011). In the 20th century, the population dramatically increased due to various factors such as agricultural, hydrological, geographical, and political benefits of the delta, which led to resettlement and construction of a new network of canals to exploit new land. Although the delta's population during undeveloped periods was not well documented, the drastic population increase over the last two centuries (Biggs, 2012) and the combined population of three provinces (Tien Giang, Vinh Long, and An Giang) demonstrate a drastic 
Nat. Hazards Earth Syst. Sci. Discuss., https://doi.org/10.5194/nhess-2017-365

Manuscript under review for journal Nat. Hazards Earth Syst. Sci.

Discussion started: 27 October 2017

(c) Author(s) 2017. CC BY 4.0 License.

population rise from 49,645 in the $1802-19$ to 522,473 in $1901-11$ and 4,896,600 in 2004. Such a remarkable transition in population appears to lead to an increased vulnerability to typhoons and other disasters because the experience of a catastrophe, which rapidly raises awareness, may not be conveyed between generations.

\section{Sea level rise and land subsidence}

In addition, MD, which extends over an extremely low-lying land, is vulnerable to a sea-level rise (SLR) and land subsidence (Takagi et al., 2016, Thanh, 2014). In particular, the subsidence rate is estimated to exceed SLR in the wider region of the delta (Takagi et al. 2016; Minderhoud et al., 2017). Groundwater exploitation is considered to be the primary cause of land subsidence. Given the increasing trends in groundwater demand in the delta, subsidence will likely be exacerbated in the near future (Minderhoud et al., 2017). Future trends in the typhoon intensity and frequency under climate change remain uncertain (IPCC, 2013). Nevertheless, recent research based on state-of-the-art models suggests that socioeconomic damage by TCs may become more severe under global warming in the western north Pacific (WNP), while the frequency of TCs approaching coastal regions is projected to decrease (Murakami et al., 2012; Ying et al. 2012; Tsuboki et al., 2015).

\section{Knowledge on storm surge and sources for prompt evacuation}

We suspected that the local people did not understand why the water level increases due to a typhoon. Although the local people were aware of a typhoon (84.5\%), only $12 \%$ of the interviewees in Con Dao realized what storm surge is (Table 2). The perception of the possible danger of storm surge among local people appears to be low. However, this result is not surprising. To understand how this has come about, the first author also conducted a similar questionnaire survey involving 39 sophomore to senior university students at his university (Fig 6). Only $35.9 \%$ realized the phenomenon of "storm surge", whereas all respondents understood a "tsunami". Even in the Philippines, which is the most typhoon prone country in the world, many local residents had not heard the vocabulary of a "storm surge" prior to the Category 5 Typhoon Haiyan in 2013 (Esteban et al., 2016). Although an official typhoon warning adequately conveyed the prediction of a massive storm surge, many local inhabitants did not understand what would happen because it was the first time that they heard the term. Training and education for public awareness are effective particularly in developing countries, which may not be able to construct hard infrastructure. The effectiveness could be realized by reviewing the case of Bangladesh where the number of deaths directly related to storm surges has decreased in the past 25 years despite a $50 \%$ increase in the number of people exposed to coastal hazards (Lumbroso, 2017). 
Nat. Hazards Earth Syst. Sci. Discuss., https://doi.org/10.5194/nhess-2017-365

Manuscript under review for journal Nat. Hazards Earth Syst. Sci.

Discussion started: 27 October 2017

(c) Author(s) 2017. CC BY 4.0 License.

(c) (i)

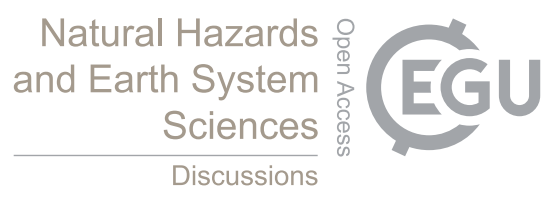

Our interview survey revealed that TV and radio were the most effective media to convey disaster warnings to local population (Table 2). It is also interesting to note that a public address system such as fixed loudspeaker substantially contributed to getting people's attentions by providing a uniform and simultaneous announcement throughout the region. On the other hand, nobody in Con Dao and Can Tho answered that they obtained the

5 information from internet sources. Since typhoon rarely occurs, they may have only recalled the situation during Linda in 1997. In 1997, there was almost no internet environment in MD to access such information. However, if the same situation happens today, it is expected that many people will obtain information from the internet.

\section{CONCLUSIONS}

It appears that coastal hazards in the Mekong Delta, particularly storm surges and typhoons, have not received as much attention by local officers, NGO, and academics as they probably deserve. Even though Typhoon Linda was the worst storm in the Mekong Delta, few studies have examined the damage it caused in Vietnam. Of the last 228 storms to make landfall in Vietnam, this tropical cyclone took the southernmost course, and the estimated reoccurrence period is only once in 150 years or longer. However, we should recall that the delta was a

15 nearly uninhabited mangrove jungle before the 20th century. Therefore, Typhoon Linda needs to be better studied to envisage a future catastrophic event and enhance the education about typhoon and storm surge of the younger generation in the Mekong Delta and the rest of Vietnam.

\section{ACKNOWLEDGEMENTS}

20 This research was funded by the Japan Society for the Promotion of Science (JSPS) KAKENHI (Grant Numbers 26702009 and 16KK0121), Heiwa Nakajima Foundation, Sumitomo Foundation, and Obayashi Foundation.

\section{REFERENCES}

Anh L. T., Takagi H., Thao N. D., Esteban M. Investigation of Awareness of Typhoon and Storm Surge in the Mekong Delta - Recollection of 1997 Typhoon Linda, Journal of Japan Society of Civil Engineers, Ser. B3 (Ocean Engineering), 73(2), pp. 168-173, 2017

Aschariyaphotha, N., Wongwises, P., Humphries, U.W. \& Wongwises, S. Study of storm surge due to Typhoon Linda (1997) in the Gulf of Thailand using a three dimensional ocean model. Applied Mathematics and Computation 217: 8640-8654., 2011. 
Nat. Hazards Earth Syst. Sci. Discuss., https://doi.org/10.5194/nhess-2017-365

Manuscript under review for journal Nat. Hazards Earth Syst. Sci.

Discussion started: 27 October 2017

(c) Author(s) 2017. CC BY 4.0 License.

Biggs D. Quagmire: Nation-building and nature in the Mekong Delta, University of Washington Press, 300p., 2012.

Central Population and Housing Census Steering Committee. The 2009 Vietnam Population and Housing Census: Major Findings, Ha Noi, 492p., 2010.

5 Danh V. T., Mushtaq S. Living with Floods: An Evaluation of the Resettlement Program of the Mekong Delta of Vietnam, M.A. Stewart and P.A. Coclanis (eds.), Environmental Change and Agricultural Sustainability in the Mekong Delta, Advances in Global Change Research 45, Springer, 181-204., 2011.

Egbert, G.D., Erofeeva, S.Y. Efficient inverse modeling of barotropic ocean tides. J. Atmos. Ocean. Technol. 19 (2), 183.204., 2002

Esteban M., Takagi H., Shibayama T. Handbook of Coastal Disaster Mitigation for Engineers and Planners, Elsevier, Page 780, 2015a.

Esteban M., Thao N. D., Takagi H., Tsimopoulou V., Mikami T., Yun N. Y., Suppasri A. The Emergence of Global Tsunami Awareness: Analysis of Disaster Preparedness in Chile, Indonesia, Japan, and Vietnam, Handbook of Coastal Disaster Mitigation for Engineers and Planners, Elsevier, pp. 205-233, 2015 b.

Esteban M., Valenzuela V. P., Matsumaru R., Mikami T., Shibayama T., Takagi H., Thao N. D., de Leon M.. Storm Surge Awareness in the Philippines Prior to Typhoon Haiyan: A Comparative Analysis with Tsunami Awareness in Recent Times, Coastal Engineering Journal, 28p, 2016.

Fritz H., Blount C. D., Thwin S., Thu M. K., Chan N. 2009, Cyclone Nargis storm surge in Myanmar, Nature Geoscience 2, 448-449, 2009

Goda, Y. Random Seas and Design of Maritime Structures, World Scientific, p. 443., 2000.

Hong Kong Observatory. Tropical Cyclones in 1997, 103 pages, 1998.

Intergovernmental Panel on Climate Change (IPCC). Climate Change 2013-The Physical Science Basis. Working Group I Contribution to the Fifth Assessment Report of the Intergovernmental Panel on Climate Change; Cambridge University Press: Cambridge, p. 1552, UK, 2013

JICA The detailed design on the Can Tho Bridge construction in Socialist Republic of Viet Nam final report: summary, 63 p., 2000.

Koutsoyiannis D. Statistics of extremes and estimation of extreme rainfall: II. Empirical investigation of long rainfall records, Hydrological Sciences Journal, 2004.

Lumbroso D. M., Suckall N. M., Nicholls R. J., White K. D., Enhancing resilience to coastal flooding from severe storms in the USA: international lessons, Nat. Hazards Earth Syst. Sci., 17, 1357-1373, 2017 
Nat. Hazards Earth Syst. Sci. Discuss., https://doi.org/10.5194/nhess-2017-365

Manuscript under review for journal Nat. Hazards Earth Syst. Sci.

Discussion started: 27 October 2017

(c) Author(s) 2017. CC BY 4.0 License.

Mikami T., Shibayama T., Takagi H., Matsumaru R., Esteban M., Thao N. D., de Leon M., Valenzuela V. P., Oyama T., Nakamura R., Kumagai K., Li S.. Storm Surge Heights and Damage Caused by the 2013 Typhoon Haiyan Along the Leyte Gulf Coast, Coastal Engineering Journal, 27 p., 2016.

Minderhoud P. S. J., Erkens G., Pham V. H., Bui V. T., Erban L., Kooi H., Stouthamer E. Impacts of 25 years of groundwater extraction on subsidence in the Mekong delta, Vietnam, Environmental Research Letters, 12(6), 2017.

Murakami H., Wang Y., Yoshimura H., Mizuta r., Sugi, M., Shido E., Adachi Y., Yukimoto S., Hosaka M., Kusunoki S., Ose T., Kitho A. Future Changes in Tropical Cyclone Activity Projected by the New HighResolution MRI-AGCM, Journal of Climate, 25, 3237-3260, 2012.

Palutikof J. P., Brabson B. B., Lister D. H., Adcock S. T., A review of methods to calculate extreme wind speeds, Meteorol. Appl. 6, 119-132, 1999.

Paul, B. K.: Why relatively fewer people died? The case of Bangladesh's Cyclone Sidr, Nat. Hazards, 50, 289304, 2009.

Shibayama T., Takagi H., Hnu N. Report of the Field Investigation after the Cyclone Nargis in 2008, Journal of Natural Disaster Science, 27(3), pp. 331-338, 2008.

Takagi H., Thao N. D., Esteban M., Mikami T., Cong L. V., Ca L. T. Coastal Disasters in Vietnam, IN: Esteban M., Takagi H., Shibayama T. (eds) Handbook of Coastal Disaster Mitigation for Engineers and Planners, Elsevier, 235-255, 2015.

Takagi H., Wu W. Maximum wind radius estimated by the $50 \mathrm{kt}$ radius: improvement of storm surge forecasting over the western North Pacific, Nat. Hazards Earth Syst. Sci., European Geosciences Union, 16, pp. 705-717, 2016.

Takagi H., Esteban M. Statistics of Tropical Cyclone Landfalls in the Philippines -Unusual Characteristics of 2013 Typhoon Haiyan, Natural Hazards, 80(1), pp. 211-222, 2016.

Takagi H., Tsurudome C., Thao, N.D., Le T. A., Tran V. T., Van P. D. T. Ocean tidal modelling for urban flood risk assessment in the Mekong Delta, Hydrological Research Letters, 10(1), pp. 21-26, 2016a.

Takagi H., Li S., de Leon M., Esteban M., Mikami T., Matsumaru R., Shibayama T., Nakamura R. Storm surge and evacuation in urban areas during the peak of a storm, Coastal Engineering, Vol. 108, pp. 1-9, 2016 b.

Takagi H., Thao N. D., Anh L. T. Sea-Level Rise and Land Subsidence: Impacts on Flood Projections for the Mekong Delta's Largest City, Sustainability, 8(9), 2016c. 
Nat. Hazards Earth Syst. Sci. Discuss., https://doi.org/10.5194/nhess-2017-365

Manuscript under review for journal Nat. Hazards Earth Syst. Sci.

Discussion started: 27 October 2017

(c) Author(s) 2017. CC BY 4.0 License.

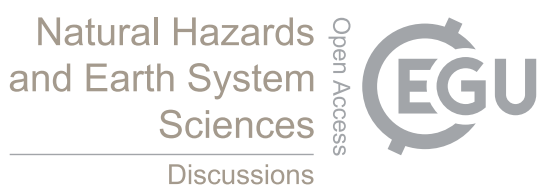

(c) (i)

Takagi H., Esteban M., Shibayama T., Mikami T., Matsumaru R., Leon M. D., Thao N. D., Oyama T. \& Nakamura R. Track analysis, simulation, and field survey of the 2013 Typhoon Haiyan storm surge, J. Flood Risk Management, 10(1), 42-52., 2017.

Taleb N. The Black Swan: The Impact of the Highly Improbable, Random House, New York, 2007.

5 Tasnim K. M., Shibayama T., Esteban M., Takagi H., Ohira K., Nakamura R. Field observation and numerical simulation of past and future storm surges in the Bay of Bengal: case study of cyclone Nargis, Natural Hazards, p. 29, 2014.

Thanh N.D. Climate Change in the Coastal Regions of Vietnam, Coastal Disasters and Climate Change in Vietnam: Engineering and Planning Perspectives 1st ed., Elsevier, 175-198, 2014.

The Nation. Thai daily newspaper, November 6, 1997.

The Nation. Thai daily newspaper, November 15, 1997.

Tsuboki K., Yoshioka M. K., Shinoda T., Kato M., Kanda S., Kitoh A. Future increase of super typhoon intensity associated with climate change, Geophysical Research Letters, 646-652, 2015.

UNDP. Summing-up report on disaster situations in recent years and preparedness and mitigation measures in Vietnam, 2003.

Wannawong W., Humphries U W., Wongwises P., Vongvisessomjai S., Lueangaram W. A two-dimensional wave prediction model along the best track of Typhoon Linda 1997, American Journal of Environmental Sciences 6 (3): 280-285, 2010.

Ying M., Knutson T. R., Kamahori H., Lee T-C., Impacts of climate change on tropical cyclones in the western north pacific basin. Part II: Late twenty-first century projections, Tropical Cyclone Research and Review, $1(2), 231-241,2012$. 
Nat. Hazards Earth Syst. Sci. Discuss., https://doi.org/10.5194/nhess-2017-365

Manuscript under review for journal Nat. Hazards Earth Syst. Sci.

Discussion started: 27 October 2017

(c) Author(s) 2017. CC BY 4.0 License.

\section{Natural Hazards and Earth System Sciences \\ Discussions}
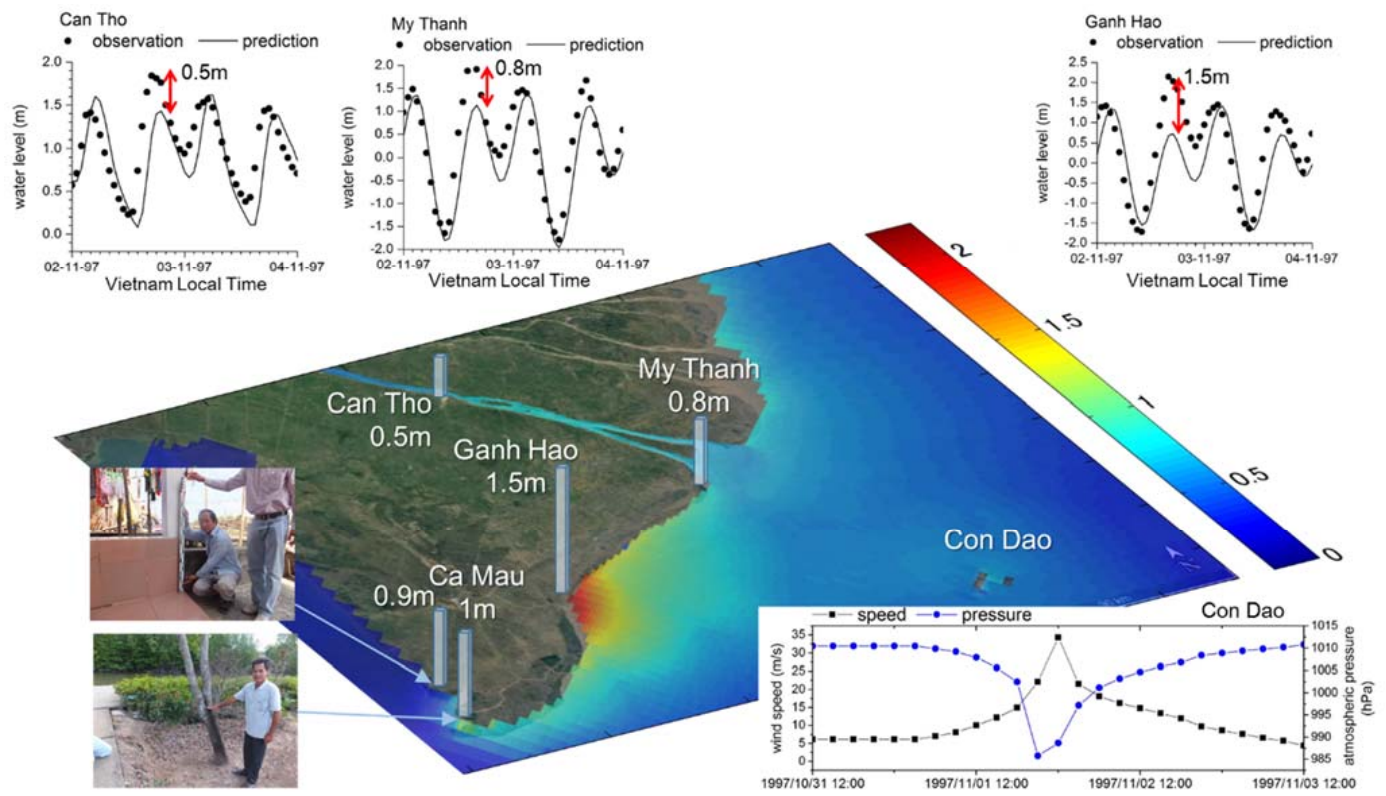

Figure 1. Storm surge induced by 1997 Typhoon Linda estimated by three methods (1. analysis with tidal constituents and observed data, 2. a typhoon-storm surge integrated model, and 3. interviews with local witnesses), showing that the overall range in MD is $0.5-1.8 \mathrm{~m}$ high. Bottom right shows the simulated wind speed 5 and atmospheric pressure at Con Dao.

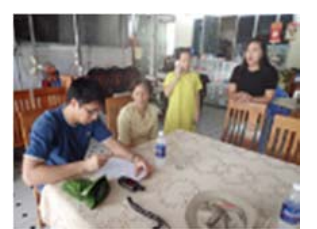

Con Dao

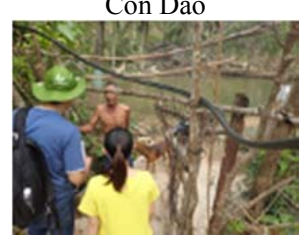

Con Dao

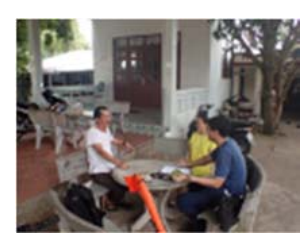

Con Dao

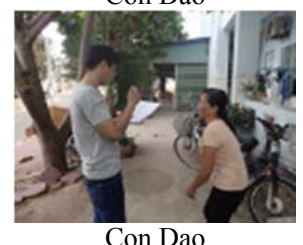

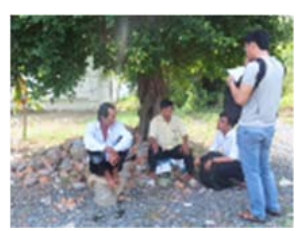

Can Tho

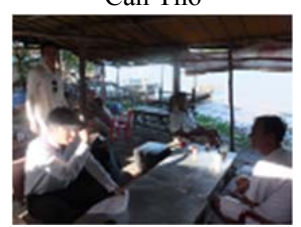

Can Tho

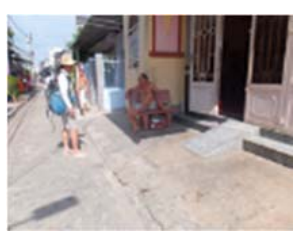

Can Tho

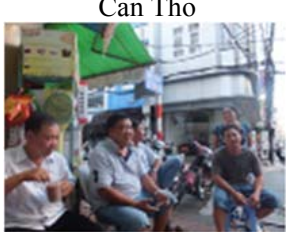

Can Tho 
Nat. Hazards Earth Syst. Sci. Discuss., https://doi.org/10.5194/nhess-2017-365

Manuscript under review for journal Nat. Hazards Earth Syst. Sci.

Discussion started: 27 October 2017

(c) Author(s) 2017. CC BY 4.0 License.

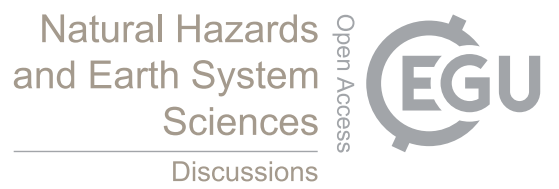

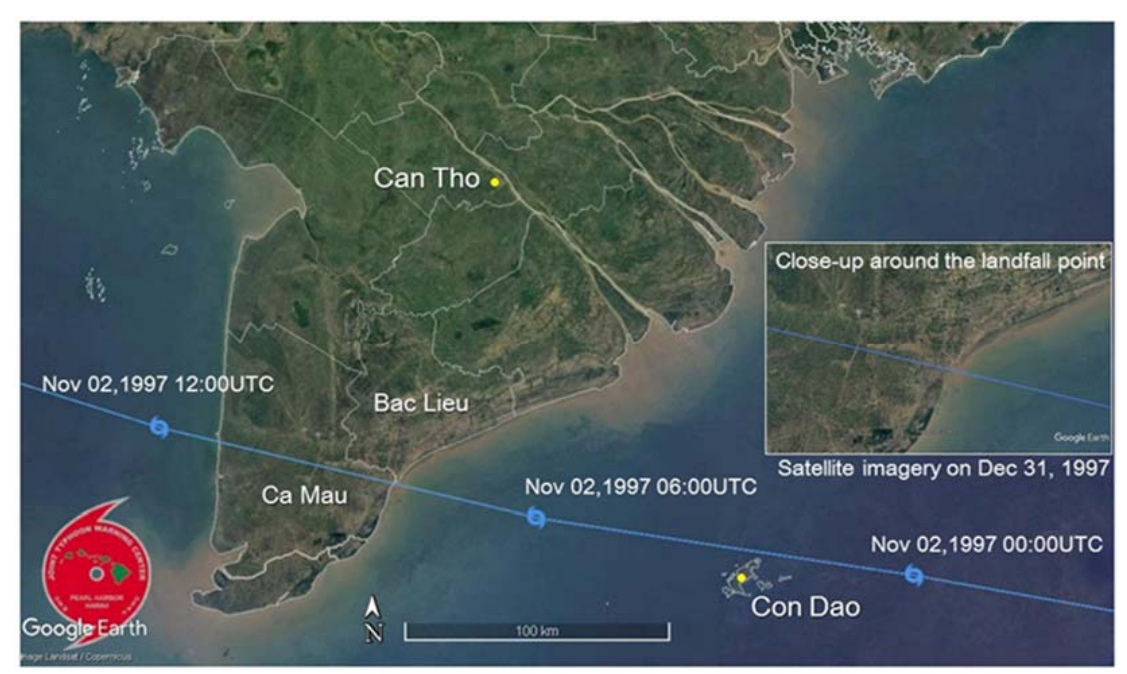

Mekong Delta and Con Dao Island

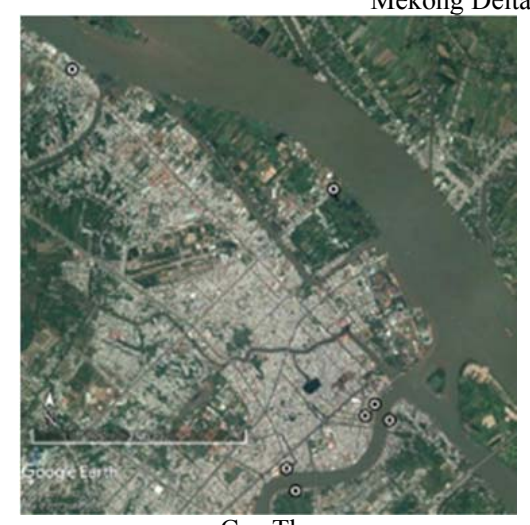

Can Tho

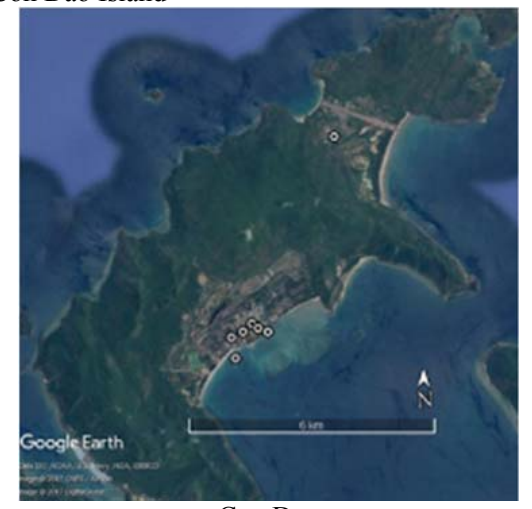

Con Dao

Figure 2. Circular plots on satellite images indicate the towns where we conducted the interview surveys and collected a total of 205 questionnaires (Con Dao: $n=103$, Can Tho: $n=102$ ). Typhoon Linda struck near the border of the Bac Lieu and Ca Mau provinces, which was a low-populated coast with a vast area of shrimp farms. Can Tho, which is the most populous city in the Mekong Delta, has 1.2 million people and is the 4th largest 5 municipality in Vietnam. Prior to the Vietnam War (1975), Con Dao was unpopulated except for political prisoners. Since then, residents have moved from the main land, leading to the present population of about 7,000. 
Nat. Hazards Earth Syst. Sci. Discuss., https://doi.org/10.5194/nhess-2017-365

Manuscript under review for journal Nat. Hazards Earth Syst. Sci.

Discussion started: 27 October 2017

(c) Author(s) 2017. CC BY 4.0 License.

\section{(c) (i)}
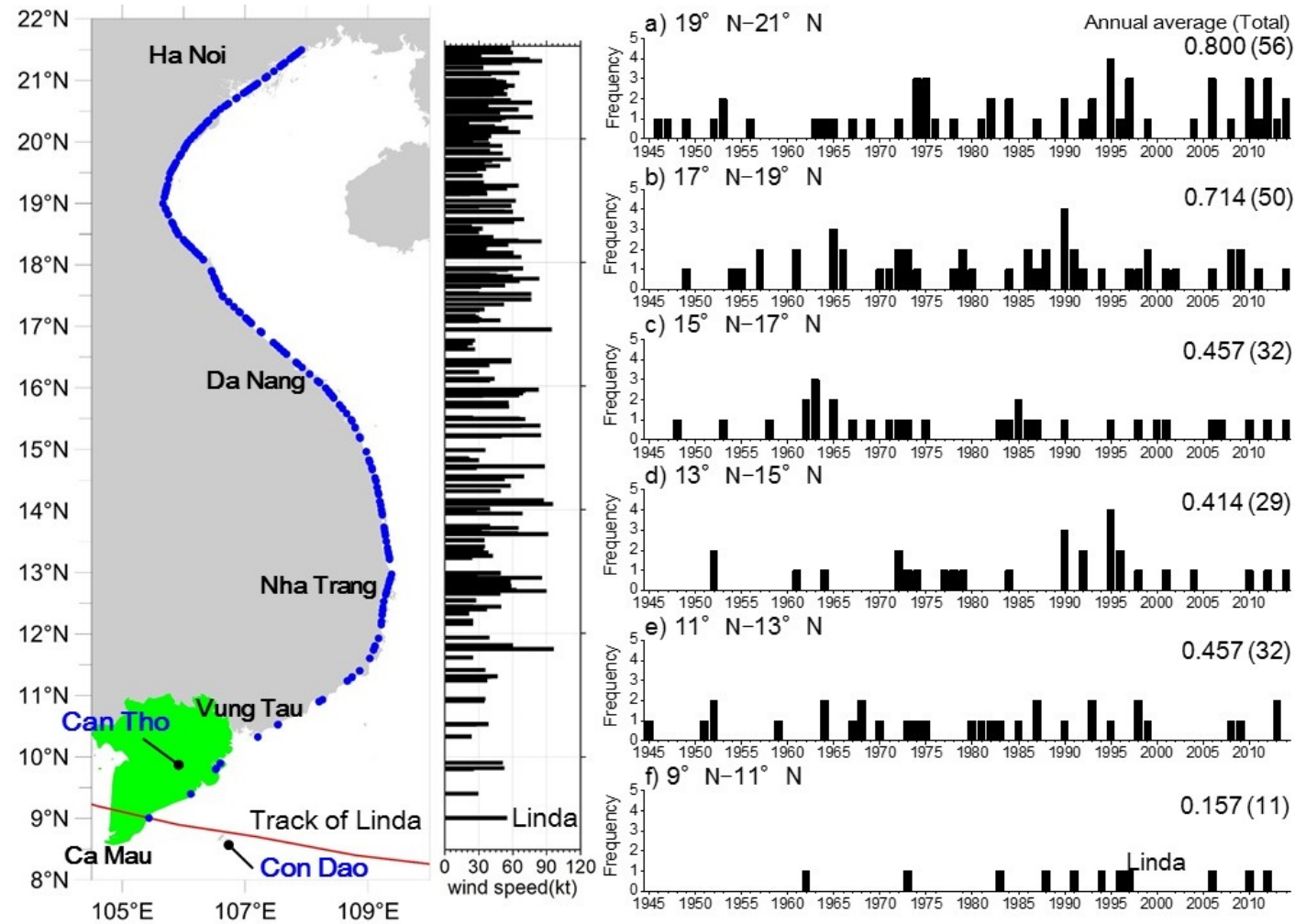

Figure 3. Landfall locations, frequency, and maximum wind speed of tropical cyclones between 1945 and 2014 estimated based on the best-track data of the Joint Typhoon Warning Centre. Area shown in green indicates MD, which is comprised of 12 provinces of Vietnam. 
Nat. Hazards Earth Syst. Sci. Discuss., https://doi.org/10.5194/nhess-2017-365

Manuscript under review for journal Nat. Hazards Earth Syst. Sci.

Discussion started: 27 October 2017

(c) Author(s) 2017. CC BY 4.0 License.
Natural Hazards 웅 and Earth System Sciences

Discussions

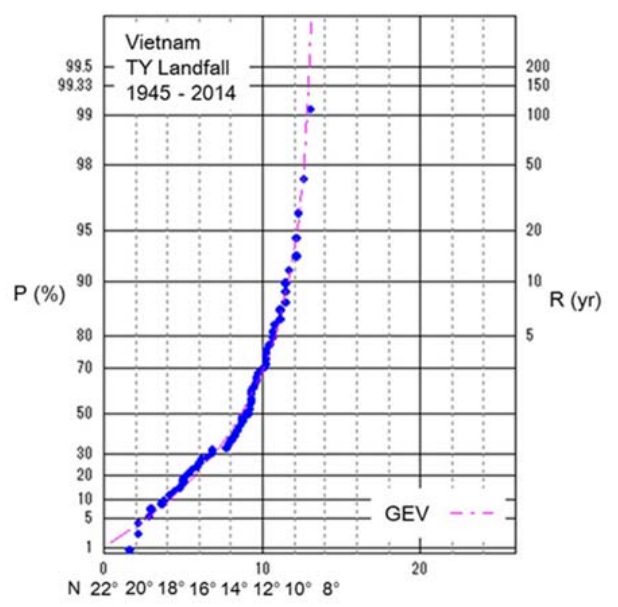

Figure 4. Extreme value statistics of Typhoon Landfall in Vietnam between 1945 and 2014 on a Gumbel probability graph. Cumulative distribution function is approximated with the generalized extreme value (GEV) distribution. P: non-exceedance probability (\%), R: return period (year)

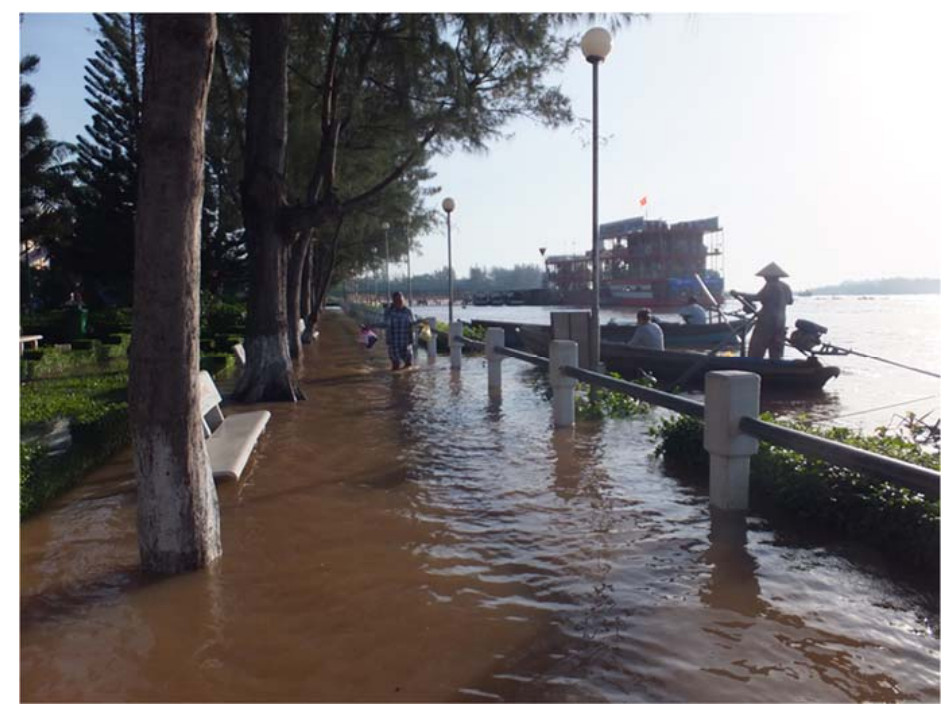

Figure 5. Scenery during an inundation in Can Tho, which is typically induced by a combination of a high tide and river discharge during flood season. Local people feel it is annoying but are not afraid of it (Photo taken by 10 the author in August 2014). 
Nat. Hazards Earth Syst. Sci. Discuss., https://doi.org/10.5194/nhess-2017-365

Manuscript under review for journal Nat. Hazards Earth Syst. Sci.

Discussion started: 27 October 2017

(c) Author(s) 2017. CC BY 4.0 License.
Natural Hazards

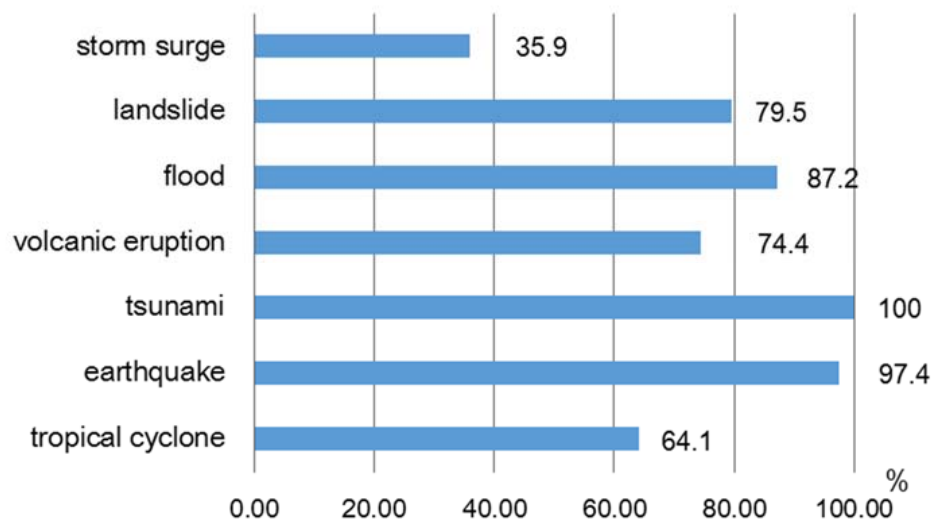

Figure 6. Questionnaire survey about the recognition of various types of natural disasters, involving 39 sophomore to senior university students $(n=39$, nationality: Japanese $=21$, Chinese $=16$, Korean $=1$, and Vietnamese $=1$ )

5

Table 1. Primary six tidal constituents, represented by amplitude $\eta(\mathrm{cm})$ and phase $\varphi$ (degree)

\begin{tabular}{ccccccccccccc}
\hline \multirow{2}{*}{ Station } & \multicolumn{2}{c}{ M2 } & \multicolumn{2}{c}{ N2 } & \multicolumn{2}{c}{ S2 } & \multicolumn{2}{c}{ K1 } & \multicolumn{2}{c}{ O1 } & \multicolumn{2}{c}{ P1 } \\
\cline { 2 - 14 } & $\eta$ & $\varphi$ & $\eta$ & $\varphi$ & $\eta$ & $\varphi$ & $\eta$ & $\varphi$ & $\eta$ & $\varphi$ & $\eta$ & $\varphi$ \\
\hline Can Tho & 51.9 & 152.4 & 9.7 & 118.7 & 17.7 & 198.0 & 35.1 & 18.2 & 21.3 & 324.3 & 8.9 & 20.6 \\
\hline My Thanh & 93.1 & 214.9 & 18.9 & 194.9 & 33.6 & 254.4 & 61.1 & 226.6 & 43.2 & 182.9 & 8.0 & 179.3 \\
\hline Ganh Hao & 80.9 & 234.9 & 16.1 & 209.3 & 26.8 & 271.6 & 59.2 & 252.1 & 39.5 & 214.0 & 17.5 & 251.5
\end{tabular}

Table 2. Questionnaire survey about the memory of 1997 Typhoon Linda and people's awareness of typhoon disaster conducted on Con Dao Island and Can Tho City.

\begin{tabular}{|c|c|c|c|}
\hline \multicolumn{2}{|l|}{ Items } & \multirow{2}{*}{$\begin{array}{c}\begin{array}{c}\text { Con Dao } \\
(n=103)\end{array} \\
49\end{array}$} & \multirow{2}{*}{$\begin{array}{c}\begin{array}{c}\text { Can Tho } \\
(n=102)\end{array} \\
44\end{array}$} \\
\hline Gender & Male & & \\
\hline & Female & 54 & 58 \\
\hline \multirow[t]{8}{*}{ Age } & 15 to $19:$ & 1 & 0 \\
\hline & 20 to 29 : & 7 & 0 \\
\hline & 30 to 39 : & 38 & 9 \\
\hline & 40 to 49 : & 29 & 27 \\
\hline & 50 to 59 : & 11 & 41 \\
\hline & 60 to $69:$ & 12 & 20 \\
\hline & 70 to $70:$ & 5 & 4 \\
\hline & Over 80: & 0 & 1 \\
\hline \multirow[t]{6}{*}{ Occupation } & Fishing/Fisheries & 14 & 0 \\
\hline & Office worker & 10 & 1 \\
\hline & Village leader & 3 & 0 \\
\hline & Driver & 3 & 4 \\
\hline & Service worker & 33 & 0 \\
\hline & Domestic worker/maid & 2 & 7 \\
\hline
\end{tabular}


Nat. Hazards Earth Syst. Sci. Discuss., https://doi.org/10.5194/nhess-2017-365

Manuscript under review for journal Nat. Hazards Earth Syst. Sci.

Discussion started: 27 October 2017

(c) Author(s) 2017. CC BY 4.0 License.

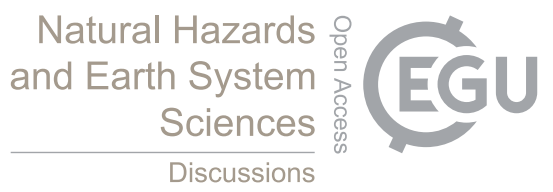

(c) (1)

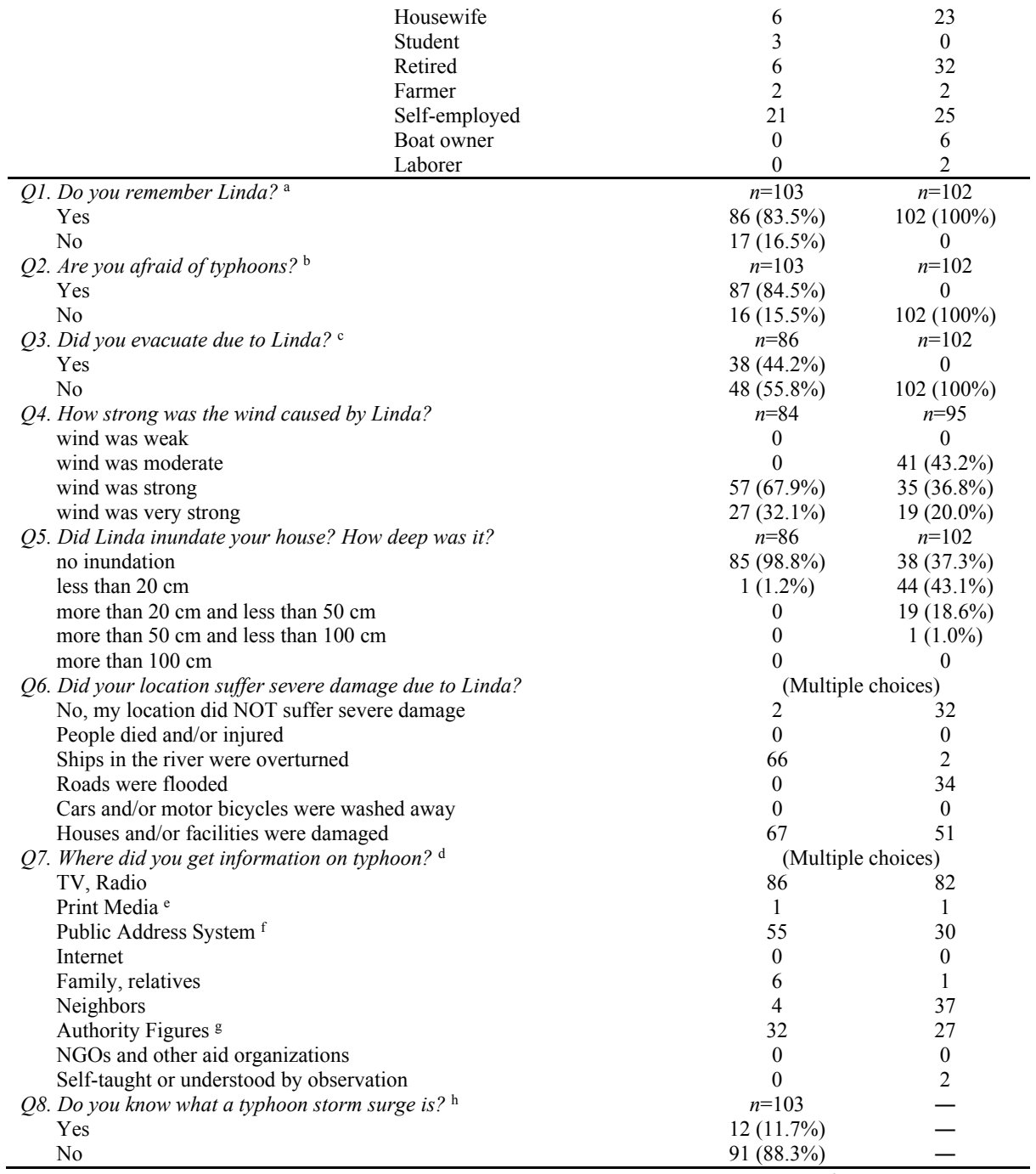

a, b, c Chi-Square test, $p<0.001,{ }^{\mathrm{d}}$ Here, we asked typhoons in general, not necessarily only during Linda, ${ }^{\mathrm{e}}$ Newspapers, Pamphlets, and Brochures, ${ }^{\mathrm{f}}$ Fixed Loudspeakers, Mobile Loudspeakers, etc., ${ }^{\mathrm{g}}$ Village Leaders, Police, Firefighters, etc., ${ }^{\mathrm{h}}$ This question was only asked in Con Dao. 